\title{
Synthesis, characterization and application of a novel mercapto- and amine-bifunctionalized silica for speciation/sorption of inorganic arsenic prior to inductively coupled plasma mass spectrometric determination
}

\author{
Ezel Boyacı ${ }^{\mathrm{a}}$, Ali Çağır ${ }^{\mathrm{a}}$, Talal Shahwan ${ }^{\mathrm{b}}$, Ahmet E. Eroğlu ${ }^{\mathrm{a}, *}$ \\ a Department of Chemistry, Izmir Institute of Technology, Urla, 35430 Izmir, Turkey \\ ${ }^{\mathrm{b}}$ Department of Chemistry, Birzeit University, Ramallah, West Bank, Palestine
}

\section{A R T I C L E I N F O}

\section{Article history:}

Received 21 January 2011

Received in revised form 31 May 2011

Accepted 11 June 2011

Available online 17 June 2011

\section{Keywords:}

Arsenic speciation

Amine-functionalized silica

Mercapto-functionalized silica

Bifunctional silica

Speciation

Inductively coupled plasma mass

spectrometry

\begin{abstract}
A B S T R A C T
A bifunctional sorbent, $\left(\mathrm{NH}_{2}+\mathrm{SH}\right)$ silica, containing both amine and mercapto functionalities was prepared by modification of silica gel with 3-(triethoxysilyl)propylamine and (3-mercaptopropyl)trimethoxysilane. In addition to the bifunctional sorbent, silica gel was modified individually with the functional mercapto- and amino-silanes, and the mono-functional sorbents, namely $(\mathrm{SH})$ silica and $\left(\mathrm{NH}_{2}\right)$ silica, were also mechanically mixed $\left(\left(\mathrm{NH}_{2}\right)\right.$ silica $+(\mathrm{SH})$ silica $)$ for the sake of comparison of sorption performances. It has been demonstrated that ( $\mathrm{SH}$ )silica shows quantitative sorption only to $\mathrm{As}(\mathrm{III})$ at two $\mathrm{pH}$ values, 1.0 and 9.0 , while $\left(\mathrm{NH}_{2}\right)$ silica displays selectivity only towards $\mathrm{As}(\mathrm{V})$ at $\mathrm{pH}$ 3.0. On the other hand, the bifunctional $\left(\mathrm{NH}_{2}+\mathrm{SH}\right)$ silica possesses the efficient features of the two mono-functionalized sorbents; for example, it retains $\mathrm{As}(\mathrm{III})$ at a wider $\mathrm{pH}$ range, from 1.0 to at least 9.0 with the exception at $\mathrm{pH} 2.0$, and it also shows quantitative sorption to $\mathrm{As}(\mathrm{V})$ at $\mathrm{pH}$ 3.0. This property gives the bifunctional $\left(\mathrm{NH}_{2}+\mathrm{SH}\right)$ silica a better flexibility in terms of sorption performance as a function of solution $\mathrm{pH}$. The mechanically mixed $\left(\mathrm{NH}_{2}\right)$ silica $+(\mathrm{SH})$ silica exhibits a similar but less efficient sorption behavior compared to the bifunctional sorbent. Desorption of both $\mathrm{As}(\mathrm{III})$ and $\mathrm{As}(\mathrm{V})$ species can be realized using $0.5 \mathrm{M} \mathrm{NaOH}$. The validity of the proposed method was checked through the analysis of a standard reference material and a good correlation was obtained between the certified $\left(26.67 \mu \mathrm{g} \mathrm{L}^{-1}\right)$ and determined $\left(27.53 \pm 0.37 \mu \mathrm{g} \mathrm{L}^{-1}\right)$ values. Spike recovery tests realized with ultrapure water $(93.0 \pm 2.3 \%)$ and drinking water $(86.9 \pm 1.2 \%)$ also confirmed the applicability of the method.
\end{abstract}

(c) 2011 Elsevier B.V. All rights reserved.

\section{Introduction}

Arsenic is an omnipresent element which is found in atmosphere, soil, rocks, natural waters as well as in biological systems, and may exist in $-3,0,+3$ and +5 oxidation states [1-4]. A variety of organic and inorganic forms can be found in nature. Each arsenic species has different chemical behaviors and toxicities. Especially, inorganic forms with the lower oxidation state are known as the most dangerous [2]. Distribution of the inorganic arsenic species in environmental samples depends on the oxidative/reductive features as well as the $\mathrm{pH}$ of the solution. Under aerobic conditions the higher oxidation states can commonly be found where arsenate $\left(\mathrm{AsO}_{4}{ }^{3-}\right)$ is the predominant $\mathrm{As}(\mathrm{V})$ species. On the other hand, under anaerobic conditions lower oxidation states are predominant and arsenite $\left(\mathrm{AsO}_{3}{ }^{3-}\right)$ is the most expected form of $\mathrm{As}(\mathrm{III})$ species $[5,6]$. Arsenic is mobilized throughout the whole ecological system

\footnotetext{
* Corresponding author. Tel.: +90 232 7507533; fax: +90 2327507509.

E-mail address: ahmeteroglu@iyte.edu.tr (A.E. Eroğlu).
}

by a series of natural processes such as volcanic emissions, weathering, leaching from rocks by ground water and biological activities. In addition, human activities such as mining, use of arsenical pesticides and wood preservatives have contributed to contamination of ground and surface waters by various arsenic species [7].

Long term consumption of drinking water contaminated with arsenic has been reported to increase the risk of cancers whereas short term exposure may result in acute poisoning with symptoms of vomiting, abdominal pain and bloody diarrhea [5,8]. Hence, drinking water contaminated with arsenic is a potential threat to the health of humans. The World Health Organization (WHO) revised the guideline for arsenic in drinking water from 0.05 to $0.01 \mathrm{mg} \mathrm{L}^{-1}$ and has classified arsenic as the most toxic chemical with carcinogenic effects [8]. Distribution and toxicity differences of arsenic species necessitate the qualitative and quantitative determination of each form separately, rather than its total concentration, in water samples.

A variety of methods have been applied for arsenic determination in various matrices. Hydride generation atomic absorption spectrometry (HGAAS) is the most widely used technique applied 
either directly or after a suitable pre-treatment step [9-11]. Hydride generation method has been reported to have the advantage of determining the different forms of arsenic (different oxidation states and forms bound to organic matter) on the basis of different kinetics of hydride generation by each species [12]. Another advantage of hydride formation is the reduction of spectral interferences by separation of the analyte from the sample matrix. However, gas phase and liquid phase interferences can be seen during or after the hydride generation step [13]. While inductively coupled plasma-mass spectrometry (ICP-MS) is one of the most sensitive techniques for As determination, the monoisotopic ${ }^{75} \mathrm{As}^{+}$ signal suffers from the spectral interference of ${ }^{40} \mathrm{Ar}^{35} \mathrm{Cl}^{+}$in the chloride-containing matrixes. This interference can be eliminated (or reduced) by matrix separation through hydride generation $[9,14]$, can be corrected with the use of interference-correction equations, or the formation of $\mathrm{ArCl}^{+}$is prevented by means of collision-cell techniques [15]. Inductively coupled plasma-atomic emission spectrometry (ICP-AES) and HG-ICP-AES are other instrumental techniques used for arsenic determination [16,17].

Speciation of inorganic arsenic can be achieved through several strategies; by manipulating the hydride forming ability of different species, by liquid-liquid extraction of As forms, or by selective adsorption of the species onto sorbents. Depending on the selectivity of the sorbent towards the lower or higher oxidation step, a pre-oxidation or pre-reduction step is necessary before sorption. For example, in a recent study, $\mathrm{As}(\mathrm{V})$ was selectively adsorbed on a solid phase adsorbent and the total inorganic arsenic content was determined after pre-oxidation of $\mathrm{As}(\mathrm{III})$ to $\mathrm{As}(\mathrm{V})$ [18]. Although, this has been a practical strategy in speciation studies, the search of new sorbents capable of retaining both species under different conditions has been an important area. An example of these types of sorbents was described by Huang et al. [19] using dimercaptosuccinic acid-modified mesoporous titanium. In the study both arsenic species were retained onto sorbent under neutral conditions while only arsenite was retained quantitatively at $\mathrm{pH} 10-11$. Alternatively, modification of the available substrates with more than one functional group can be a promising strategy for speciation studies. Functionalization of the solid supports can be realized by functional silane coupling reagents. The polysiloxane sorbents functionalized with mercapto and amine groups are revealed in the literature as effective in the removal of metal ions [20-26] and $\mathrm{Hg}$ (II) $[27,28]$. In addition, bifunctional sorbents containing two functionalities (amine and mercapto) on the same sorbent had been prepared and used for the removal of metal ions [29]. The advantage of the bifunctionalization can also be seen by the extraction of a wide spectrum of the hard and soft metal ions by the prepared sorbents.

The affinity of mercapto functionality to lower [30,31] and amine functionality to higher [32] oxidation state of arsenic has evoked the search for a bifunctional sorbent with both groups. From this point of view, the main purpose of the present study was to synthesize a novel bifunctional solid phase extraction sorbent with both mercapto and amine functional groups and to use the sorbent for selective sorption of arsenic species.

\section{Experimental}

\subsection{Instrumentation and apparatus}

An inductively coupled plasma mass spectrometer (ICP-MS, Agilent 7500ce Series, Tokyo, Japan) was employed in the determination of arsenic concentrations at $\mathrm{m} / \mathrm{z}$ : 75 . In order to prevent the possible matrix-based polyatomic interference of ${ }^{40} \mathrm{Ar}^{35} \mathrm{Cl}^{+}$on ${ }^{75} \mathrm{As}^{+}$signal, chloride-containing acids or solvents were not used in the preparation of solutions except during desorption with $\mathrm{KIO}_{3}$ which also contained $\mathrm{HCl}$. Still, in case the use of any chloride species would be inevitable in the pre-measurement steps, the optimization of ICP-MS parameters was carried out in the collision mode in octopole reaction system with He gas.

In batch sorption studies, GFL 1083 water bath shaker (Burgwedel, Germany) equipped with a microprocessor thermostat was used for mixing. The $\mathrm{pH}$ of the solutions was adjusted with 0.01-1.0 $\mathrm{M} \mathrm{HNO}_{3}$ and $0.01-1.0 \mathrm{M} \mathrm{NH}_{3}$ using Ino Lab Level 1 $\mathrm{pH}$ meter (Weilheim, Germany). The elemental composition of sorbents was determined by a LECO-CHNS-932 elemental analyzer (Mönchengladbach, Germany). Microimages of sorbents were obtained utilizing a Philips XL-30S FEG scanning electron microscope (Eindhoven, The Netherlands). The thermal properties of sorbents were examined using a Perkin Elmer Pyris Diamond TG/DTA (Boston, MA, USA). Surface area measurements of the sorbents were performed with Micromeritics Gemini V Series Surface Area Analyzer (Norcross, USA).

\subsection{Reagents and solutions}

All the chemicals were of analytical reagent grade. Deionized ultrapure water $(18.2 \mathrm{M} \Omega \mathrm{cm})$ was used throughout the study. Glassware and plastic containers were cleaned by soaking in $10 \%$ $(\mathrm{v} / \mathrm{v})$ nitric acid for $24 \mathrm{~h}$ and rinsed with deionized water prior to use.

Stock standard solutions of $\mathrm{As}(\mathrm{V})$ and $\mathrm{As}(\mathrm{III}), 2000.0 \mathrm{mg} \mathrm{L}^{-1}$, were prepared by dissolving $\mathrm{As}_{2} \mathrm{O}_{5}$ (Merck, product code: 1.09939, CAS no.: [1303-28-2]) and $\mathrm{As}_{2} \mathrm{O}_{3}$ (Fischer, CAS no.: [1327-53-3]), respectively, in ultrapure water. Lower concentration standard solutions were prepared daily by appropriate dilution from their stock standards before use.

Silica gel was purchased from Merck (product code: 1.10184, CAS no.: [7631-86-9]) and activated with acetic acid (Riedel-de Haen, product code: 27225, CAS no.: [64-19-7]). Functionalization of silica gel was realized with 3-(triethoxysilyl)propylamine (APTES) (Merck, product code: 8.26619, CAS no.: [14814-09-6]) and (3-mercaptopropyl)trimethoxysilane (MPTMS)(Fluka, product code: 63800, CAS no.: [4420-74-0]), respectively. Toluene (Riedelde-Haen, product code: 24529 , CAS no.: [108-88-3]) was used both as a reaction solvent and for removal of the unreacted reagent after modification step; and acetone (Merck, product code: 1.00014, CAS no.: [67-64-1]) as a further washing solvent. Nitric acid (Merck, product code: 1.00456, CAS no.: [7697-37-2]) was employed for the acidification of samples prior to ICP-MS determination. LCysteine (Merck, product code: 1.02838, CAS no.: [52-90-4]) at a concentration of $1.0 \%(\mathrm{w} / \mathrm{v})$ was used as the eluent for the desorption of $\mathrm{As}(\mathrm{V})$ whereas the eluent for $\mathrm{As}(\mathrm{III})$ desorption was $0.050 \mathrm{M}$ $\mathrm{KIO}_{3}$ (Merck, product code: 1.02404 , CAS no.: [7758-05-6]) in $2.0 \mathrm{M}$ $\mathrm{HCl}$ (Merck, product code: 1.00314, CAS no.: [7647-01-0]).

\subsection{Synthesis of the sorbents}

The procedure utilized in the functionalization of the silica surface was compiled from literature [33] with some modifications. The first step is the activation of the silica surface to convert the siloxane groups to silanol. For this purpose, $5.00 \mathrm{~g}$ of silica was treated with $50.0 \mathrm{~mL}$ of $0.010 \mathrm{M}$ acetic acid for $1 \mathrm{~h}$ and then washed with ultrapure water until a neutral filtrate was obtained. This step was completed after drying the activated silica at $120^{\circ} \mathrm{C}$ for $24 \mathrm{~h}$ in a vacuum oven. The amine modification step was carried out by mixing $5.0 \mathrm{~g}$ of activated silica, $3.0 \mathrm{~mL}$ of APTES and $9.0 \mathrm{~mL}$ toluene in a two necked $25 \mathrm{~mL}$ flask. A condenser having anhydrous $\mathrm{CaCl}_{2}$ drying tube at the top was connected to the reaction flask. The reaction was proceeded under an inert atmosphere provided with $\mathrm{N}_{2}$ bubbled through the side arm of the flask. The mixture was stirred for $24 \mathrm{~h}$ at $100 \mathrm{rpm}$ under constant reflux in an oil bath at a temperature 
Table 1

Summary of the parameters and ranges used throughout the study.

\begin{tabular}{ll}
\hline Parameters investigated & Range \\
\hline pH of solution & $1.0,2.0,3.0,4.0,5.0,7.0,8.0$ and 9.0 \\
Amount of sorbent $(\mathrm{mg})$ & $5.0,10.0,25.0,50.0$ and 100.0 \\
Shaking time (min) & $1,5,15,30,60$ and 120 \\
Solution temperature $\left({ }^{\circ} \mathrm{C}\right)$ & 25,50 and 75 \\
\hline
\end{tabular}

of $110^{\circ} \mathrm{C}$. After the reaction had been completed, amine-treated silica was washed sequentially with $10.0 \mathrm{~mL}$ portions of acetone and toluene and then dried in an oven at $50^{\circ} \mathrm{C}$ overnight. The same procedure was applied for mercapto-modification of the silica using (3-mercaptopropyl)trimethoxysilane instead of APTES. Bifunctionalization of the silica was realized with the simultaneous addition of the same amounts of both functional silanes into the reaction mixture under the same experimental conditions.

\subsection{Characterization of the sorbents}

A variety of methods were applied for the characterization of the modified silica samples. Elemental analysis was used for the determination of nitrogen, sulfur and carbon contents. Images and elemental mapping of unmodified silica (silica), mercaptomodified silica ((SH)silica), amine-modified silica $\left(\left(\mathrm{NH}_{2}\right)\right.$ silica) and mercapto-amine bifunctionalized silica $\left(\left(\mathrm{NH}_{2}+\mathrm{SH}\right)\right.$ silica $)$ were obtained using scanning electron microscopy (SEM). Surface area and thermal gravimetric degradation behavior of the sorbents were also investigated.

\subsection{Sorption studies}

Sorption studies were performed through a batch process for all the sorbents prepared; namely, silica, $(\mathrm{SH})$ silica, $\left(\mathrm{NH}_{2}\right)$ silica and $\left(\mathrm{NH}_{2}+\mathrm{SH}\right)$ silica. In order to examine the possible changes in the sorption of bifunctionalized sorbent, a mechanical (1:1) mixture of amine-modified silica and mercapto-modified silica $\left(\mathrm{NH}_{2}\right)$ silica $+(\mathrm{SH})$ silica was also prepared as an alternative sorbent for the bifunctional silica.

Batch sorption studies were carried out at $25^{\circ} \mathrm{C}$ with each sorbent separately after the initial $\mathrm{pH}$ of solutions was adjusted to 1.0, 2.0, 3.0, 4.0, 5.0, 7.0, 8.0 and 9.0 with dilute $\mathrm{HNO}_{3}$ or $\mathrm{NH}_{3}$. After $\mathrm{pH}$ adjustment step, $50.0 \mathrm{mg}$ sorbent was added into each of the $50 \mathrm{~mL}$ centrifuge tubes containing $20.0 \mathrm{~mL}$ aliquots of $100.0 \mu \mathrm{g} \mathrm{L}^{-1} \mathrm{As}(\mathrm{V})$ or $100.0 \mu \mathrm{g} \mathrm{L}^{-1} \mathrm{As}(\mathrm{III})$ solutions. The mixtures were placed in a thermostated water bath shaker and shaken for $30 \mathrm{~min}$, then they were filtered through blue-band filter papers. The filtrates were analyzed for arsenic concentration by ICP-MS. Prior to ICP-MS measurements all samples and standard solutions were acidified with the addition of appropriate amounts of concentrated $\mathrm{HNO}_{3}$ to produce $1.0 \%$ $(\mathrm{v} / \mathrm{v}) \mathrm{HNO}_{3}$ in the final solution. The effects of the amount of sorbent, shaking time, solution temperature and repetitive use of the sorbents were investigated throughout the study. The investigated parameters and ranges are summarized in Table 1.

\subsection{Desorption studies}

Initial desorption studies were performed on oxidation-reduction basis of the sorbed $\mathrm{As}(\mathrm{III})$ and $\mathrm{As}(\mathrm{V})$. For the oxidation of $\mathrm{As}(\mathrm{III})$ to $\mathrm{As}(\mathrm{V}), 0.050 \mathrm{M} \mathrm{KIO}_{3}$ in $2.0 \mathrm{M} \mathrm{HCl}$ was used while $1.0 \%(\mathrm{w} / \mathrm{v})$ L-cysteine solution with $\mathrm{pH}$ adjusted to 3.0 was the eluent for the reduction of $\mathrm{As}(\mathrm{V})$ to $\mathrm{As}(\mathrm{III})$. In addition to the oxidative-reductive eluents, $0.50 \mathrm{M} \mathrm{NaOH}$ and $0.50 \mathrm{M} \mathrm{HNO}_{3}$ were also used as alternative. Matrix-matched standardization was applied in each case. Before desorption studies, the following parameters were used for $\mathrm{As}(\mathrm{III})$ sorption: arsenite ion concentra- tion of $100.0 \mu \mathrm{g} \mathrm{L}^{-1}$, solution volume of $20.0 \mathrm{~mL}$, sorbent amount of $50.0 \mathrm{mg}$, shaking time of $30 \mathrm{~min}$, reaction temperature of $25^{\circ} \mathrm{C}$ and solution pHs of 1.0, 3.0, 5.0 and 8.0. In the case of $\mathrm{As}(\mathrm{V})$, similar sorption parameters were applied at the solution $\mathrm{pH}$ of 3.0.

\subsection{Method validation}

The proposed methodology was validated both through the analysis of a standard reference material (SRM from NIST, Natural Water - Trace Elements, Cat. No. 1640) and via spike recovery experiments. $\left(\mathrm{NH}_{2}+\mathrm{SH}\right)$ silica was used in the validation study because of the absence of information about the oxidation state of arsenic in the reference material. Before the sorption/desorption steps, the acid content of the SRM was removed in a way that $5.0 \mathrm{~mL}$ of the solution was diluted with $10.0 \mathrm{~mL}$ of ultrapure water in a Teflon beaker and the mixture was evaporated to dryness. The residue in the beaker was dissolved in $10 \mathrm{~mL}$ of ultrapure water, transferred to a centrifuge tube where $\mathrm{pH}$ was adjusted to 3.0, diluted to $15.0 \mathrm{~mL}$, and then used in the sorption/desorption. The expected concentration of the SRM in the final solution was, thus, $8.89 \mu \mathrm{g} \mathrm{L}^{-1}$.

In addition to SRM analysis, the applicability of the methodology was also tested by spike recovery tests using drinking water. The spike concentration was $30.0 \mu \mathrm{g} \mathrm{L}^{-1}$ as this value was close to the concentration of SRM $\left(26.67 \mu \mathrm{gL}^{-1}\right)$. Moreover, similar dilution and $\mathrm{pH}$ adjustment steps were employed before the sorption/desorption cycles.

\section{Results and discussion}

As explained in Section 2.1, concentration of arsenic species in the final solutions was determined using ICP-MS at $m / z$ ratio of 75 . In case the use of any chloride species would be inevitable in the pre-measurement steps, the optimization of ICP-MS parameters was carried out in the collision mode in octopole reaction system with He gas in order to prevent the possible matrix-based polyatomic interference of ${ }^{40} \mathrm{Ar}^{35} \mathrm{Cl}^{+}$on ${ }^{75} \mathrm{As}^{+}$signal. Under the studied conditions, the calibration line equation was $y=1836.5 x+370.3$ with a correlation coefficient of $R^{2}=0.9991$. The limit of detection $\left(\mathrm{LOD}_{3 \mathrm{~s}}\right)$ and the limit of quantitation $\left(\mathrm{LOQ}_{10 \mathrm{~s}}\right)$ were $0.041 \mu \mathrm{g} \mathrm{L}^{-1}$ and $0.135 \mu \mathrm{g} \mathrm{L}^{-1}$, respectively. These figures of merits were considered to be sufficient for the purpose of the study; therefore, no attempt was tried to enhance these values.

\subsection{Characterization of sorbents}

The results of the surface area and pore width measurements of the prepared sorbents (Table 2 ) indicate that the modification has slightly decreased both the surface area and the pore size of the novel sorbents with respect to the unmodified silica. These results indicate the modification of the silica surface with the employed functional groups. The extent of modification was also followed by the characterization of the functional groups on the basis of surface $\mathrm{N}, \mathrm{S}, \mathrm{C}$, and $\mathrm{H}$ contents. The elemental analysis results are given in Table 3. As seen, $\left(\mathrm{NH}_{2}\right)$ silica contains $2.14 \%$ nitrogen while (SH)silica contains $3.73 \%$ sulfur. The bifunctional sorbent containing both mercapto and amine groups, on the other hand, has $1.03 \%$

Table 2

Surface area and pore width results.

\begin{tabular}{lll}
\hline & BET surface area $\left(\mathrm{m}^{2} \mathrm{~g}^{-1}\right)$ & Average pore size $(\AA ̊)$ \\
\hline Silica & 253.9 & 17.3 \\
$\left(\mathrm{NH}_{2}\right)$ silica & 168.9 & 14.1 \\
$(\mathrm{SH})$ silica & 189.6 & 14.1 \\
$\left(\mathrm{NH}_{2}+\mathrm{SH}\right)$ silica & 183.9 & 14.1 \\
\hline
\end{tabular}


Table 3

Elemental analysis results (\%).

\begin{tabular}{lllll}
\hline & $\mathrm{C}$ & $\mathrm{H}$ & $\mathrm{N}$ & $\mathrm{S}$ \\
\hline$\left(\mathrm{NH}_{2}\right)$ silica & 6.03 & 1.63 & 2.14 & - \\
$(\mathrm{SH})$ silica & 5.62 & 1.31 & - & 3.73 \\
$\left(\mathrm{NH}_{2}+\mathrm{SH}\right)$ silica & 6.48 & 1.51 & 1.03 & 2.52 \\
\hline
\end{tabular}

nitrogen and $2.52 \%$ sulfur. The modification of the silica surface with the organic groups is also indicated by thermal gravimetric analysis (TGA) curves of the sorbents, as given in Fig. 1. Unmodified silica shows two-stage weight losses at the thermal ranges of $25-200{ }^{\circ} \mathrm{C}(4 \%)$ and $200-600^{\circ} \mathrm{C}(2.4 \%)$. This is possibly caused by the removal of physically adsorbed water, and a further loss caused by the condensation of free silanol groups to siloxane groups on the surface of silica, respectively [34]. $\left(\mathrm{NH}_{2}\right)$ silica has a characteristic weight loss (4.6\%) between 25 and $200{ }^{\circ} \mathrm{C}$ due to the removal of physically adsorbed water, and a second loss (7.1\%) between 200 and $600{ }^{\circ} \mathrm{C}$ possibly because of the thermal decomposition of the organic functional groups of the modified silica. Similarly, (SH)silica displays $1.5 \%$ and $10.2 \%$ weight losses in the same temperature ranges for the same reasons. Similarly, $\left(\mathrm{NH}_{2}+\mathrm{SH}\right)$ silica has a characteristics thermograph between $(\mathrm{SH})$ silica and $\left(\mathrm{NH}_{2}\right)$ silica with weight losses of $3.0 \%$ and $9.5 \%$ corresponding, respectively, to the removal of physisorbed water and the thermal degradation of organic functional groups.

\subsection{Sorption studies}

\subsubsection{Effect of $p H$ on the sorption of $A s(I I I)$ and $A s(V)$}

The sorption percentages of the sorbents towards $\mathrm{As}(\mathrm{III})$ and $\mathrm{As}(\mathrm{V})$ as a function of $\mathrm{pH}$ are shown in Fig. 2. The unmodified silica shows no appreciable sorption to any of the two As species. Alternatively, (SH)silica shows quantitative sorption only to As(III) at the two extreme points in the investigated $\mathrm{pH}$ range, namely, $\mathrm{pH}$ 1.0 and 9.0 while $\mathrm{As}(\mathrm{V})$ is not retained. This result is in accordance with similar literature studies which suggest that mercapto group is selective generally to the lower oxidation states of the hydride forming elements $[30,31,35,36]$. On the other hand, $\left(\mathrm{NH}_{2}\right)$ silica demonstrates selectivity only towards $\mathrm{As}(\mathrm{V})$, and this response is indicative of the affinity of amine functionality to arsenate ion. The nature of sorption at $\mathrm{pH} 3.0$ has been suggested, in a previous study, as being electrostatic attraction between the protonated amine groups of $\left(\mathrm{NH}_{2}\right)$ silica and $\mathrm{H}_{2} \mathrm{AsO}_{4}{ }^{-}$ion, which is the main species at this $\mathrm{pH}[32]$.

As can be deduced from Fig. 2(a) and (b), the most striking feature of the bifunctional $\left(\mathrm{NH}_{2}+\mathrm{SH}\right)$ silica, in contrast to $(\mathrm{SH})$ silica,

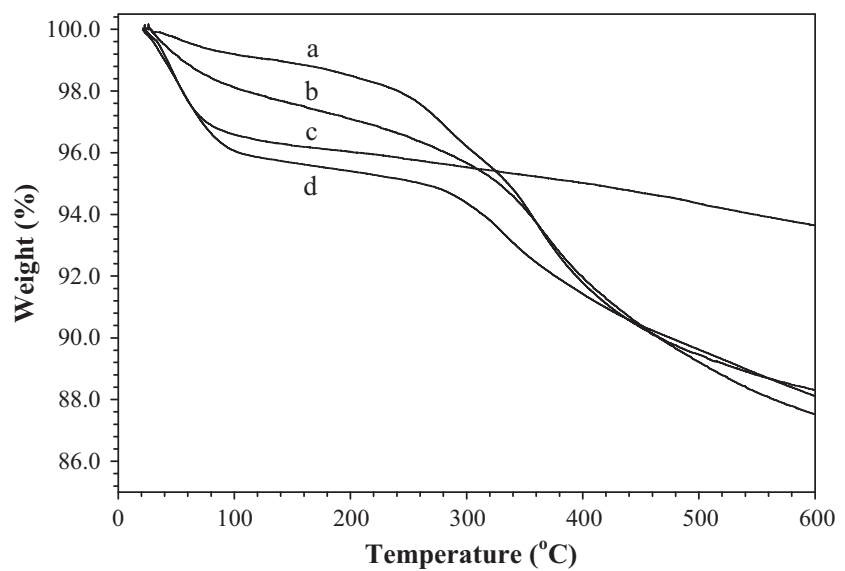

Fig. 1. TGA curves of (a) (SH)silica, (b) $\left(\mathrm{NH}_{2}+\mathrm{SH}\right)$ silica, (c) unmodified silica, and (d) $\left(\mathrm{NH}_{2}\right)$ silica.
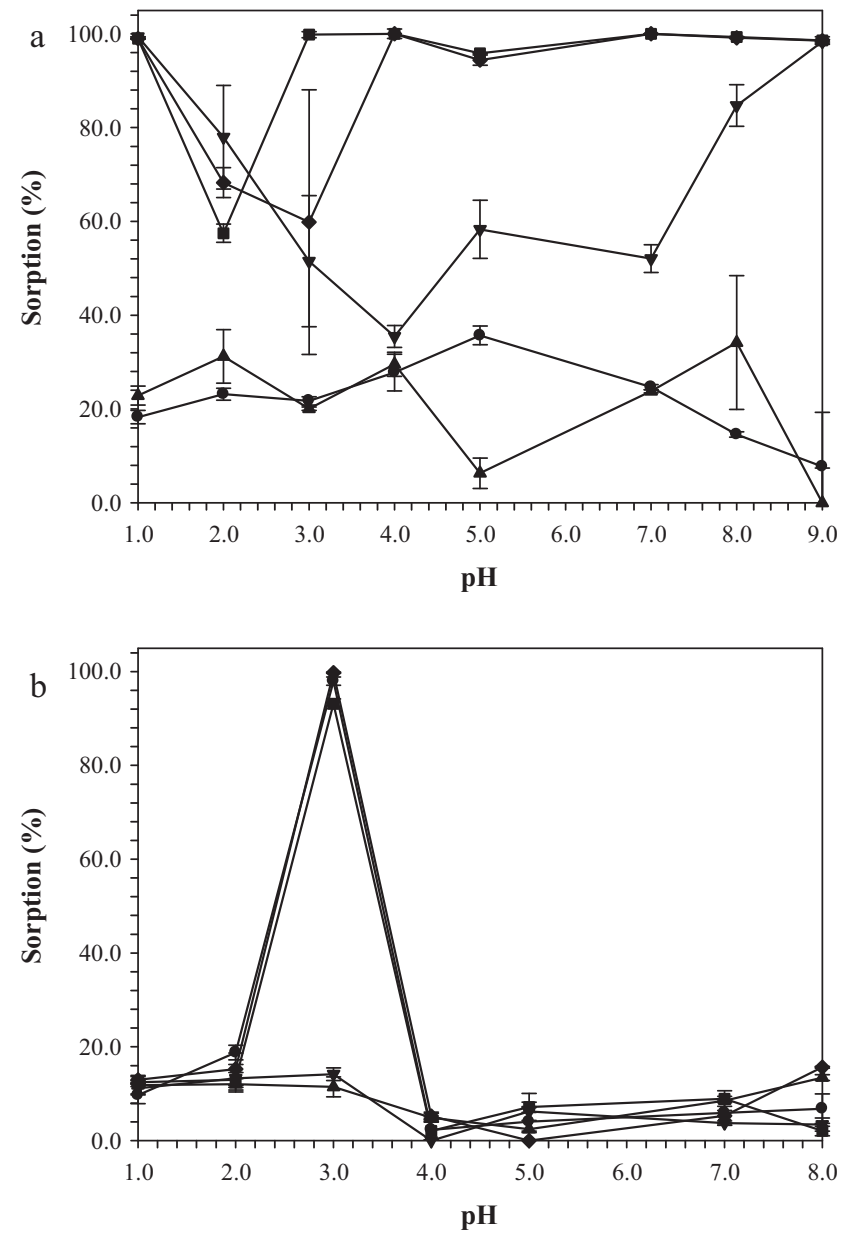

Fig. 2. Effect of $\mathrm{pH}$ on the sorption of $100.0 \mu \mathrm{gL}^{-1}$ (a) $\mathrm{As}(\mathrm{III})$ and (b) $\mathrm{As}(\mathrm{V})$

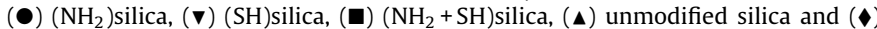
$\left(\mathrm{NH}_{2}\right)$ silica + $(\mathrm{SH})$ silica (reaction time: $30 \mathrm{~min}$, sorbent amount: $50.0 \mathrm{mg}$, sample volume: $20.0 \mathrm{~mL}$, sorption temperature: $25^{\circ} \mathrm{C}, n=3$ ). Error bars indicate the standard deviation of the triplicate measurements at $95 \% \mathrm{CL}$.

is its quantitative sorption capability towards As(III) at a relatively wide $\mathrm{pH}$ range. The bifunctional sorbent can be used for As(III) sorption from $\mathrm{pH} 1.0$ to at least 9.0 with an exception at $\mathrm{pH} 2.0$ only. This improvement in the sorption percentage of the bifunctional sorbent compared to (SH)silica needs further investigation and, for the present, can be attributed to the synergistic effect of the amine groups on the sorbent in addition to the mercapto groups. Another important property of $\left(\mathrm{NH}_{2}+\mathrm{SH}\right)$ silica is that it can be applied for the quantitative sorption of $\mathrm{As}(\mathrm{V})$ at $\mathrm{pH}$ 3.0. From these results, it can be argued that the bifunctional sorbent possesses the efficient features of the two functional groups. In addition, with a simple $\mathrm{pH}$ adjustment step (to pHs greater than 4.0) before the sorption, $\left(\mathrm{NH}_{2}+\mathrm{SH}\right)$ silica can be employed for the sorption of As(III) only; or for the sorption of both $\mathrm{As}(\mathrm{III})$ and $\mathrm{As}(\mathrm{V})$ simultaneously at $\mathrm{pH}$ 3.0. A similar but less efficient sorption behavior was also observed with the mechanically mixed $\left(\mathrm{NH}_{2}\right)$ silica $+(\mathrm{SH})$ silica. The sorbent mixture can be used for the sorption of As(III) quantitatively at a wide $\mathrm{pH}$ range but, in contrast to $\left(\mathrm{NH}_{2}+\mathrm{SH}\right)$ silica, there is not a single $\mathrm{pH}$ for the simultaneous quantitative sorption of $\mathrm{As}(\mathrm{III})$ and $\mathrm{As}(\mathrm{V})$. The percentage sorption of the sorbent mixture to As(III) at $\mathrm{pH} 3.0$ is not reproducible.

The results outlined in the previous two paragraphs have demonstrated the high flexibility of the sorbent systems developed in the present study. Depending on the purpose of investigation, that is whether $\mathrm{As}(\mathrm{III})$ or $\mathrm{As}(\mathrm{V})$ is to be determined, either $\left(\mathrm{NH}_{2}\right)$ silica or $(\mathrm{SH})$ silica can be used after a $\mathrm{pH}$ adjustment step. In 
addition to the mono-functionalized silicas, a better strategy could be the application of the bifunctional $\left(\mathrm{NH}_{2}+\mathrm{SH}\right)$ silica due to its selectivity to either $\mathrm{As}(\mathrm{III})$ or both $\mathrm{As}(\mathrm{III})$ and $\mathrm{As}(\mathrm{V})$ after a simple $\mathrm{pH}$ adjustment step.

\subsubsection{As(III) sorption}

The percentage sorption of the mono-functional $(\mathrm{SH})$ silica, the bifunctional $\left(\mathrm{NH}_{2}+\mathrm{SH}\right)$ silica and the mechanically mixed $\left(\mathrm{NH}_{2}\right)$ silica + $(\mathrm{SH})$ silica towards $\mathrm{As}(\mathrm{III})$ was investigated at three $\mathrm{pH}$ values decided from Fig. 2, namely, $\mathrm{pH}$ 1.0, 3.0, and 9.0. The solution $\mathrm{pH}$ of 1.0 and 9.0 were chosen since the percentage sorption of the related sorbents was quantitative at these pHs. In addition, the percentage sorption was also examined at $\mathrm{pH} 3.0$ which is a critical $\mathrm{pH}$ for $\mathrm{As}(\mathrm{V})$ as well. For all $\mathrm{pHs}$, the effects of the sorbent amount, the reaction time, and the reaction temperature were studied. The related results regarding As(III) sorption are given as Supporting Information in Figs. 1S-3S, whereas those of $\mathrm{As}(\mathrm{V})$ are shown in Fig. 4S.

3.2.2.1. $\mathrm{pH}$ 1.0. The results of the As(III) sorption studies carried out at $\mathrm{pH} 1.0$ are summarized in Fig. 1S. As can be seen from Fig. 1S(a), the quantitative sorption was obtained at the sorbent amount of $50.0 \mathrm{mg}$ for $\left(\mathrm{NH}_{2}+\mathrm{SH}\right)$ silica and $\left(\mathrm{NH}_{2}\right)$ silica $+(\mathrm{SH})$ silica, whereas a lower amount of ( $\mathrm{SH})$ silica $(25.0 \mathrm{mg})$ was sufficient to attain a saturation plateau. The indicated sorbents showed a similar sorption behavior as a function of reaction time, and 30.0 min was sufficient to obtain a quantitative sorption (Fig. 1S(b)). The effect of reaction temperature on sorption is shown in Fig. $1 \mathrm{~S}(\mathrm{c})$. The graph reveals a slight exothermic nature of the sorption, with the percentage sorption amounting to more than $95 \%$ sorption even at $75^{\circ} \mathrm{C}$.

3.2.2.2. $p H$ 9.0. The results of the sorption studies obtained at the solution $\mathrm{pH}$ of 9.0 were similar to those at $\mathrm{pH} 1.0$, as shown in Fig. 2S. For (SH)silica and $\left(\mathrm{NH}_{2}\right)$ silica $+(\mathrm{SH})$ silica, quantitative sorption was obtained with $50.0 \mathrm{mg}$ sorbent amount, whereas $25.0 \mathrm{mg}$ of $\left(\mathrm{NH}_{2}+\mathrm{SH}\right)$ silica was sufficient to reach the maximum sorption (Fig. $2 \mathrm{~S}(\mathrm{a})$ ). As seen in Fig. $2 \mathrm{~S}(\mathrm{~b})$, the bifunctional $\left(\mathrm{NH}_{2}+\mathrm{SH}\right)$ silica demonstrated faster sorption behavior, and even $5.0 \mathrm{~min}$ of contact time was sufficient to exceed $96 \%$ sorption percentage. For $(\mathrm{SH})$ silica and $\left(\mathrm{NH}_{2}\right)$ silica $+(\mathrm{SH})$ silica, it was necessary to shake the mixture for at least $30.0 \mathrm{~min}$ to attain a saturation plateau. The reaction temperature did not have a significant influence on sorption and the percentage sorption was always quantitative at all the examined temperatures (Fig. 2S(c)).

3.2.2.3. $p H$ 3.0. It has been demonstrated in Section 3.2.1 that the solution $\mathrm{pH}$ of 3.0 deserved a more close examination. Fig. 2(a) shows that the reproducibility of sorption by the mono-functionalized ( $\mathrm{SH}$ )silica and the mechanically mixed $\left(\mathrm{NH}_{2}\right)$ silica $+(\mathrm{SH})$ silica was not good at $\mathrm{pH} 3.0$, as can be concluded from the wide error bars whereas the bifunctional $\left(\mathrm{NH}_{2}+\mathrm{SH}\right)$ silica displayed a better sorption performance. Additional experiments were carried out in order to investigate the sorption behavior of the chosen sorbents at $\mathrm{pH} 3.0$, and the results are summarized in Fig. 3S. As can be seen from the figure, the bifunctional $\left(\mathrm{NH}_{2}+\mathrm{SH}\right)$ silica always demonstrated a superior sorption behavior over the other two sorbents. A sorbent amount of only $25.0 \mathrm{mg}$ and a reaction time of $30.0 \mathrm{~min}$ were sufficient to achieve maximum sorption. In the case of the mechanically mixed $\left(\mathrm{NH}_{2}\right)$ silica $+(\mathrm{SH})$ silica, a higher amount $(50.0 \mathrm{mg})$ and a longer equilibration time $(120.0 \mathrm{~min})$ were necessary to attain quantitative sorption. The situation was completely different for the mono-functionalized (SH)silica for which the quantitative sorption was never obtained even with the increase in the sorbent amount. Although longer shaking times increased the sorption percentage, as shown in Fig. 3S(b), quantitative sorption was never

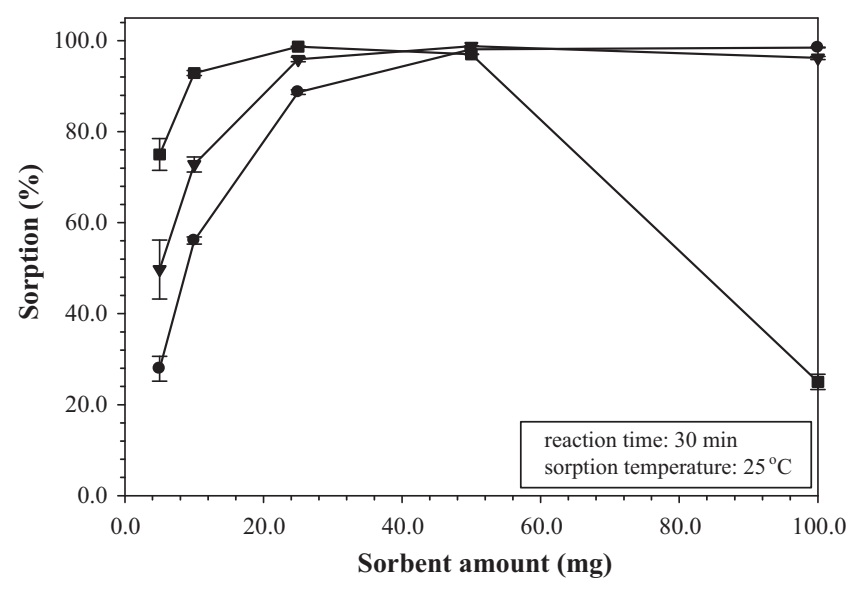

Fig. 3. Effect of the sorbent amount on the sorption of $100.0 \mu \mathrm{gL}^{-1} \mathrm{As}(\mathrm{V})$ $\left((\mathbf{\square})\left(\mathrm{NH}_{2}\right)\right.$ silica, $(\bullet)\left(\mathrm{NH}_{2}+\mathrm{SH}\right)$ silica, $(\boldsymbol{\nabla})\left(\mathrm{NH}_{2}\right)$ silica $+(\mathrm{SH})$ silica, sample volume: $20.0 \mathrm{~mL}$, solution $\mathrm{pH} 3.0, n=3)$.

approached and the results were irreproducible. The effect of reaction temperature elucidated important differences in the performances of the sorbents. Fig. $3 \mathrm{~S}(\mathrm{c})$ indicates that the extent of sorption on the bi-functional $\left(\mathrm{NH}_{2}+\mathrm{SH}\right)$ silica and the mechanically mixed $\left(\mathrm{NH}_{2}\right)$ silica $+(\mathrm{SH})$ silica were slightly affected by temperature change within the range of $25-75^{\circ} \mathrm{C}$, and tended to display exothermic behavior. On the other hand, the sorption behavior of the mono-functionalized ( $\mathrm{SH}$ )silica was distinctively endothermic, with the sorption percentage increasing drastically form $52 \%$ at $25^{\circ} \mathrm{C}$ to about $95 \%$ at $75^{\circ} \mathrm{C}$.

\subsection{3. $A s(V)$ sorption}

The percentage sorption of the mono-functional $\left(\mathrm{NH}_{2}\right)$ silica, the bifunctional $\left(\mathrm{NH}_{2}+\mathrm{SH}\right)$ silica and the mechanically mixed $\left(\mathrm{NH}_{2}\right)$ silica $+(\mathrm{SH})$ silica towards $\mathrm{As}(\mathrm{V})$ was investigated at $\mathrm{pH}$ 3.0. This was the only $\mathrm{pH}$ at which $\left(\mathrm{NH}_{2}\right)$ silica displayed quantitative sorption (see Fig. 2(b)) and therefore, any comparison among the selected sorbents containing amine functionality can only be performed at this point. In this context, the effects of the sorbent amount, the reaction time, and the reaction temperature were studied and the results are shown in related figures. The percentage sorption graphs of $\left(\mathrm{NH}_{2}\right)$ silica, $\left(\mathrm{NH}_{2}+\mathrm{SH}\right)$ silica and $\left(\mathrm{NH}_{2}\right)$ silica $+(\mathrm{SH})$ silica as a function of sorbent amount demonstrate the different behaviors of these sorbents towards $\mathrm{As}(\mathrm{V})$ (Fig. 3). For all the sorbents, $50.0 \mathrm{mg}$ appears to be an optimum quantity for maximum sorption. This amount forms the point at which a saturation plateau was reached for $\left(\mathrm{NH}_{2}+\mathrm{SH}\right)$ silica and $\left(\mathrm{NH}_{2}\right)$ silica $+(\mathrm{SH})$ silica. The most noticeable and unexpected feature of the figure, however, is the decrease of the percentage sorption for the mono-functional $\left(\mathrm{NH}_{2}\right)$ silica after $50.0 \mathrm{mg}$. In order to test whether (or not) this observation is actually due to the increase in sorbent amount, a detailed $\mathrm{pH}$ study was performed, bearing in mind the observation that the sorption of $\left(\mathrm{NH}_{2}\right)$ silica is restricted to $\mathrm{pH}$ 3.0. For this purpose, sorption was carried out in both buffered and unbuffered $\mathrm{As}(\mathrm{V})$ solutions. The percentage sorption results are shown in Fig. 4 together with the change in the solution $\mathrm{pH}$ as a function of the sorbent amount. From these results it can be argued that the decrease in the sorption percentage occurs as a consequence of the change in the solution $\mathrm{pH}$, rather than being related with the sorbent amount. This finding was made further clear by monitoring the variation in the solution $\mathrm{pH}$ as a function of time for different amounts of the sorbent $\left(\mathrm{NH}_{2}\right)$ silica (Fig. 5). As can be deduced from the figure, the solution $\mathrm{pH}$ is shifted to even basic pHs in a few seconds in the unbuffered solution, depending on the amount of $\left(\mathrm{NH}_{2}\right)$ silica. The reason for the increase in the solution $\mathrm{pH}$ 


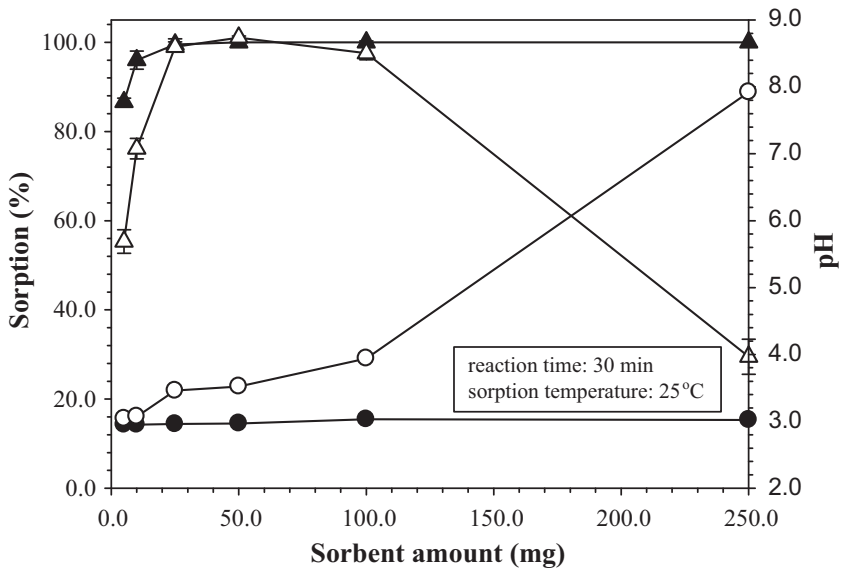

Fig. 4. Effect of the amount of $\left(\mathrm{NH}_{2}\right)$ silica on the sorption of $100.0 \mu \mathrm{g} \mathrm{L}^{-1} \mathrm{As}(\mathrm{V})$ in $(\triangle)$ unbuffered and $(\Delta)$ buffered solutions (variation of $\mathrm{pH}$ in $(\bigcirc)$ unbuffered and (๑) buffered solutions), sample volume: $20.0 \mathrm{~mL}$, solution $\mathrm{pH} 3.0, n=3$.

must be protonation of the amine functional groups in $\left(\mathrm{NH}_{2}\right)$ silica and thereby decreasing the hydronium ion concentration in the solution. Since any $\mathrm{pH} \geq 4.0$ is not suitable for the sorption of $\mathrm{As}(\mathrm{V})$, the sorption percentage decreases. Moreover, the amount where the sorption percentage starts to decrease may be affected by the percentage of the amine functional groups used in the modification of the silica surface, and probably also by batch-to-batch variations. This result demonstrates further the superior performance of the bifunctional $\left(\mathrm{NH}_{2}+\mathrm{SH}\right)$ silica over the mono-functional $\left(\mathrm{NH}_{2}\right)$ silica.

The effect of the reaction time on the sorption percentages of the selected sorbents, namely, $\left(\mathrm{NH}_{2}\right)$ silica, $\left(\mathrm{NH}_{2}+\mathrm{SH}\right)$ silica and $\left(\mathrm{NH}_{2}\right)$ silica $+(\mathrm{SH})$ silica was also investigated and the results are shown in Fig. 6. As shown in the figure, with small differences, all three sorbents exhibit similar performance in the time interval of 5-60 min. The sorption percentage is higher than $85 \%$ even within the initial 5 min of contact, indicating ease of accessibility to the sorbent groups/sorption sites. As in the previous section, and in relation with the amount of sorbent, the sorption percentage obtained with $\left(\mathrm{NH}_{2}\right)$ silica decreases to below $20 \%$ in a very short time. In order to enlighten this issue, a detailed pH study was again carried out in both buffered and unbuffered $\mathrm{As}(\mathrm{V})$ solutions. The percentage sorption results together with the change in the solution $\mathrm{pH}$ in the course of the reaction are shown in Fig. 7. From these results it can be suggested that the decrease in percentage

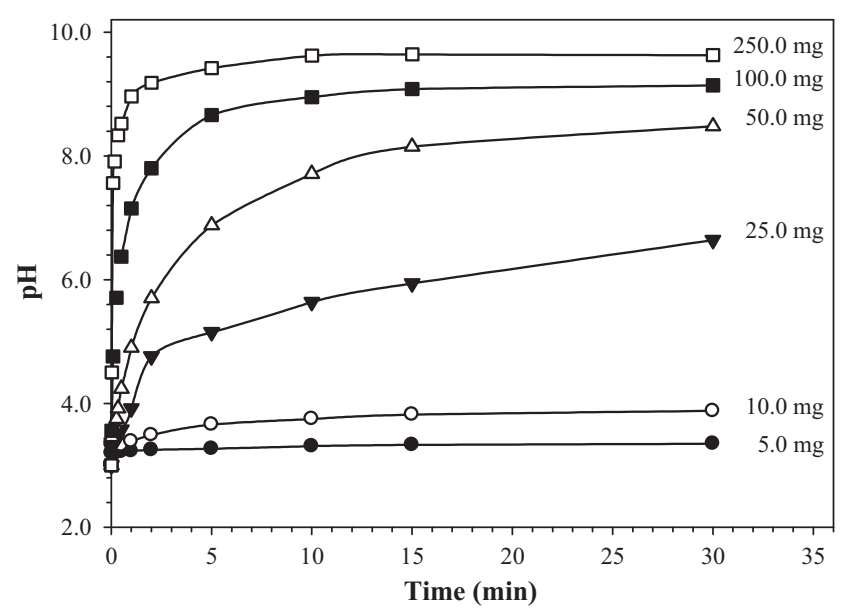

Fig. 5. Variation in the solution $\mathrm{pH}$ as a function of reaction time for different amounts of $\left(\mathrm{NH}_{2}\right)$ silica, sample volume: $20.0 \mathrm{~mL}$, solution pH 3.0 (experiment were performed under unbuffered conditions).

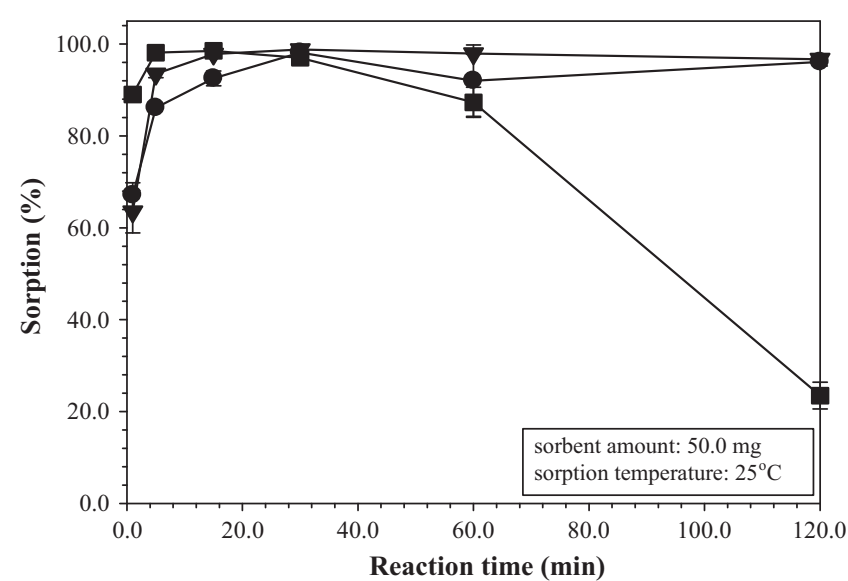

Fig. 6. Effect of the reaction time on the sorption of $100.0 \mu \mathrm{gL}^{-1} \mathrm{As}(\mathrm{V})$ $\left((\boldsymbol{\square})\left(\mathrm{NH}_{2}\right)\right.$ silica, $(\bullet)\left(\mathrm{NH}_{2}+\mathrm{SH}\right)$ silica, $(\boldsymbol{\nabla})\left(\mathrm{NH}_{2}\right)$ silica $+(\mathrm{SH})$ silica, sample volume: $20.0 \mathrm{~mL}$, solution $\mathrm{pH} 3.0, n=3)$.

sorption can once again be referred to the change in the solution $\mathrm{pH}$, and is not a consequence of the reaction time. This conclusion can also be drawn from Fig. 5 which shows that, depending on the amount of $\left(\mathrm{NH}_{2}\right)$ silica in the unbuffered solution, the solution $\mathrm{pH}$ was not equal to 3.0, and has immediately shifted to higher values in a matter of seconds where no sorption of $\mathrm{As}(\mathrm{V})$ occurs. This result illustrates, once again, the better sorption performance of the bifunctional over the mono-functional silica.

The effect of reaction temperature on the sorption of $\mathrm{As}(\mathrm{V})$ by the selected sorbents is shown in Fig. 4S (supporting information). As explained in the previous two paragraphs, the sorption percentage is strongly affected by the solution $\mathrm{pH}$, and buffering the solution at $\mathrm{pH} 3.0$ had always a positive influence on the extent of sorption. At $25^{\circ} \mathrm{C}$ and under the employed experimental conditions, all three sorbents displayed quantitative sorption in both the unbuffered and the buffered solutions although the pHs of the unbuffered solutions after the sorption step had risen to $8.05,6.90$, and 6.50 for $\left(\mathrm{NH}_{2}\right)$ silica, $\left(\mathrm{NH}_{2}\right)$ silica $+(\mathrm{SH})$ silica and $\left(\mathrm{NH}_{2}+\mathrm{SH}\right)$ silica, respectively. These high sorption results can be ascribed to the fast kinetics of the sorption with the selected sorbents. At $50^{\circ} \mathrm{C}$, the sorption of $\left(\mathrm{NH}_{2}\right)$ silica and $\left(\mathrm{NH}_{2}\right)$ silica $+(\mathrm{SH})$ silica in the unbuffered solutions have decreased below $10 \%$ whereas the respective sorption results were $83 \%$ and $76 \%$ in the buffered solutions. Although these results are indicative of exothermic nature of sorption with these two sorbents,

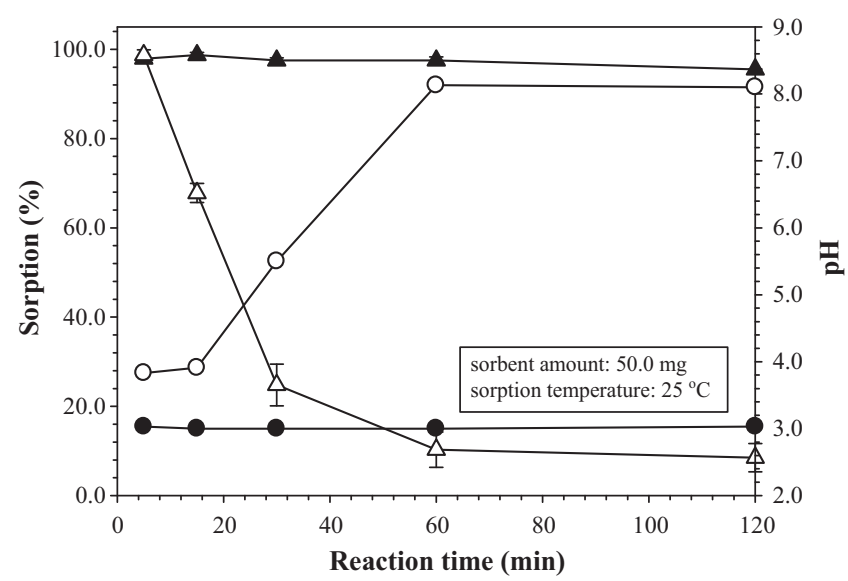

Fig. 7. Effect of the reaction time on the sorption of $100.0 \mu \mathrm{g} \mathrm{L}^{-1} \mathrm{As}(\mathrm{V})$ by $\left(\mathrm{NH}_{2}\right)$ silica in $(\triangle)$ unbuffered and $(\boldsymbol{\Delta})$ buffered solutions (variation of $\mathrm{pH}$ in $(\bigcirc)$ unbuffered and ( ) buffered solutions), sample volume: $20.0 \mathrm{~mL}$, solution pH 3.0, $n=3$. 
Table 4

Summary of Dubinin-Radushkevich coefficients (solution volume, shaking time and reaction temperature were $20.0 \mathrm{~mL}, 30 \mathrm{~min}$ and $25^{\circ} \mathrm{C}$, respectively, $n=3$ ).

\begin{tabular}{|c|c|c|c|c|}
\hline Parameter & $\left(\mathrm{SH}+\mathrm{NH}_{2}\right)$ silica & $(\mathrm{SH})$ silica $+\left(\mathrm{NH}_{2}\right)$ silica & (SH)silica & $\left(\mathrm{NH}_{2}\right)$ silica \\
\hline \multicolumn{5}{|l|}{ As(III) } \\
\hline \multicolumn{5}{|l|}{ pH 1.0} \\
\hline$R^{2}$ & 0.9802 & 0.9759 & 0.9897 & \\
\hline$Q_{\max }(\mathrm{mmol} / \mathrm{g})$ & 0.0063 & 0.0072 & 0.0072 & - \\
\hline$E(\mathrm{~kJ} / \mathrm{mol})$ & 15.8 & 15.8 & 22.4 & \\
\hline \multicolumn{5}{|l|}{$\mathrm{pH} 3.0$} \\
\hline$R^{2}$ & 0.982 & 0.9956 & 0.9974 & \\
\hline$Q_{\max }(\mathrm{mmol} / \mathrm{g})$ & 0.0360 & 0.0210 & 0.0470 & - \\
\hline$E(\mathrm{~kJ} / \mathrm{mol})$ & 12.9 & 12.9 & 9.1 & \\
\hline \multicolumn{5}{|l|}{ pH 9.0} \\
\hline$R^{2}$ & 0.9851 & 0.861 & 0.9844 & \\
\hline$Q_{\max }(\mathrm{mmol} / \mathrm{g})$ & 0.0390 & 0.0021 & 0.0044 & - \\
\hline$E(\mathrm{~kJ} / \mathrm{mol})$ & 12.9 & 22.4 & 15.8 & \\
\hline \multicolumn{5}{|l|}{$\mathrm{As}(\mathrm{V})$} \\
\hline \multicolumn{5}{|l|}{ pH 3.0} \\
\hline$R^{2}$ & 0.9660 & 0.9966 & & 0.9962 \\
\hline$Q_{\max }(\mathrm{mmol} / \mathrm{g})$ & 0.0039 & 0.0121 & - & 0.1312 \\
\hline$E(\mathrm{~kJ} / \mathrm{mol})$ & 15.8 & 12.9 & & 11.2 \\
\hline
\end{tabular}

it seems that the sudden decrease in sorption can be attributed to the increase in the solution $\mathrm{pH}$ to values where no sorption occurs, rather than being a thermal effect. Following the sorption step, the $\mathrm{pH}$ values of the solutions were 8.50 and 7.83 for $\left(\mathrm{NH}_{2}\right)$ silica and $\left(\mathrm{NH}_{2}\right)$ silica $+(\mathrm{SH})$ silica, respectively. This finding also shows the importance of buffering the solutions if $\left(\mathrm{NH}_{2}\right)$ silica or $\left(\mathrm{NH}_{2}\right)$ silica $+(\mathrm{SH})$ silica are planned to be used. The situation for the bifunctional $\left(\mathrm{NH}_{2}+\mathrm{SH}\right)$ silica was different from the two sorbents in a way that the sorption was again quantitative for both the unbuffered and the buffered solutions. At $75^{\circ} \mathrm{C}$, the sorption decreased to almost $0 \%$ for the unbuffered, and below $25 \%$ for the buffered solutions, for $\left(\mathrm{NH}_{2}\right)$ silica and $\left(\mathrm{NH}_{2}\right)$ silica $+(\mathrm{SH})$ silica, respectively. For $\left(\mathrm{NH}_{2}\right)$ silica and $\left(\mathrm{NH}_{2}\right)$ silica $+(\mathrm{SH})$ silica, the $\mathrm{pH}$ values of the unbuffered solutions following the sorption step were 8.70 and 7.76, respectively. On the other hand, the $\mathrm{pH}$ did not change in the buffered solutions and the decrease in the sorption percentage can, therefore, be ascribed to exothermic nature of sorption on these two sorbents. The sorption of $\left(\mathrm{NH}_{2}+\mathrm{SH}\right)$ silica was not affected by the temperature increase and was quantitative even at $75^{\circ} \mathrm{C}$. These results verifies the robust nature and the applicability of the bifunctional $\left(\mathrm{NH}_{2}+\mathrm{SH}\right)$ silica even at such relatively unusual conditions.

In addition to the sorption studies with $\mathrm{As}(\mathrm{III})$ and $\operatorname{As}(V)$, the capacity of the sorbents was determined via Dubinin-Radushkevich (D-R) isotherm model, as explained in a previous study [32]. The model was applied at pH 1.0, 3.0 and 9.0 for $\mathrm{As}(\mathrm{III})$ and $\mathrm{pH} 3.0$ for $\mathrm{As}(\mathrm{V})$. The results are summarized in Table 4 . The linear correlation coefficients $\left(R^{2}\right)$ were generally high, suggesting that the isotherm is suitable for describing the sorption of both arsenic species. During the sorption studies, the arsenic amount was $0.00053 \mathrm{mmol} \mathrm{As} / \mathrm{g}$ sorbent (As initial concentration: $100.0 \mu \mathrm{g} \mathrm{L}^{-1}$, solution volume: $20.0 \mathrm{~mL}$ and sorbent amount: $50.0 \mathrm{mg}$ ) and according to the maximum sorption capacity, $Q_{\max }$, values of the sorbents (Table 4) only a small fraction of the capacity of the sorbents appears to be used for sorption, which is ascribed to the low initial sorbate concentration. Overall, the calculated values of sorption energy correspond to electrostatic type of interaction.

\subsection{Desorption studies}

\subsubsection{Desorption of As(III)}

As explained in Section 2.6, the first strategy followed for desorption of As(III) from (SH)silica, $\left(\mathrm{NH}_{2}+\mathrm{SH}\right)$ silica and $\left(\mathrm{NH}_{2}\right)$ silica $+(\mathrm{SH})$ silica was to oxidize the adsorbed $\mathrm{As}(\mathrm{III})$ to $\mathrm{As}(\mathrm{V})$ using the oxidative eluent $0.050 \mathrm{M} \mathrm{KIO}_{3}$ in $2.0 \mathrm{M} \mathrm{HCl}$. This eluent desorbed $\mathrm{As}(\mathrm{III})$ over $89 \%$ by oxidizing to $\mathrm{As}(\mathrm{V})$ when the sorption was performed at $\mathrm{pH}$ values of 1.0 and 3.0; and lower desorption (between 70 and $77 \%$ ) was achieved when sorption was performed at $\mathrm{pH}$ of 5.0 and 8.0 . In the case of $0.50 \mathrm{M} \mathrm{NaOH}$, almost complete desorption of As(III) was observed which was possibly caused by removal of functional groups of the sorbents when sorption was realized at $\mathrm{pH}$ values of 1.0 and 3.0. On the other hand, desorption percentages were between 60 and 70 when sorption was carried out at $\mathrm{pH}$ values of 5.0 and 8.0. The wide range of the desorption percentages obtained using the same eluent at different sorption $\mathrm{pH}$ values can be ascribed to the different types of interaction of the analyte ion with the functional groups on the modified silicas.

\subsubsection{Desorption of $A s(V)$}

A similar strategy was followed for elution of $\mathrm{As}(\mathrm{V})$ from $\left(\mathrm{NH}_{2}\right)$ silica, $\left(\mathrm{NH}_{2}+\mathrm{SH}\right)$ silica and $\left(\mathrm{NH}_{2}\right)$ silica $+(\mathrm{SH})$ silica by reducing the adsorbed $\mathrm{As}(\mathrm{V})$ to $\mathrm{As}(\mathrm{III})$ with L-cysteine. The results showed that nearly $90 \%$ desorption was achieved from $\left(\mathrm{NH}_{2}\right)$ silica while $\left(\mathrm{NH}_{2}+\mathrm{SH}\right)$ silica and $\left(\mathrm{NH}_{2}\right)$ silica $+(\mathrm{SH})$ silica underwent only $20 \%$ and $57 \%$ desorption percentages, respectively. A possible reason for the lower desorption with mercapto containing sorbents is the affinity of the mercapto group towards As(III) produced after reduction step. The second strategy to elute $\mathrm{As}(\mathrm{V})$ from the sorbents was to leach the sorbent with $0.50 \mathrm{M} \mathrm{HNO}_{3}$ or $0.5 \mathrm{M} \mathrm{NaOH}$. The desorption percentage of the $\mathrm{As}(\mathrm{V})$ when $\mathrm{HNO}_{3}$ is used as eluent from $\left(\mathrm{NH}_{2}\right)$ silica and $\left(\mathrm{NH}_{2}\right)$ silica $+(\mathrm{SH})$ silica was above $85 \%$, but this eluent was not much effective for $\left(\mathrm{NH}_{2}+\mathrm{SH}\right)$ silica (43\% desorption). $0.50 \mathrm{M} \mathrm{NaOH}$ was able to desorp $\mathrm{As}(\mathrm{V})$ over $92 \%$ from each sorbent. The main reason for desorption of arsenate from the prepared sorbents can be explained by the leaching of the functional groups (amino and/or mercapto) from the silica surface under basic conditions.

\subsection{Reusability of the sorbents}

Based on the results of sorption studies, the $\mathrm{pH}$ of 3.0 had been chosen as the critical pH for sorption and speciation studies. For this reason, the reusability of the sorbents was tested at $\mathrm{pH}$ of 3.0 for both arsenic forms. For $\mathrm{As}(\mathrm{V}), 1.0 \%(\mathrm{~m} / \mathrm{v})$ L-cysteine was used as the eluent for $\left(\mathrm{NH}_{2}\right)$ silica, $0.50 \mathrm{M} \mathrm{NaOH}$ for $\left(\mathrm{NH}_{2}\right)$ silica, $\left(\mathrm{NH}_{2}\right)$ silica $+(\mathrm{SH})$ silica and $\left(\mathrm{NH}_{2}+\mathrm{SH}\right)$ silica, and $0.50 \mathrm{M} \mathrm{HNO}_{3}$ for $\left(\mathrm{NH}_{2}\right)$ silica, $\left(\mathrm{NH}_{2}\right)$ silica $+(\mathrm{SH})$ silica and $\left(\mathrm{NH}_{2}+\mathrm{SH}\right)$ silica. The results demonstrate that $\left(\mathrm{NH}_{2}\right)$ silica can be used at least 5 times when $1.0 \%$ $(\mathrm{m} / \mathrm{v}) \mathrm{L}$-cysteine is used as the eluent since more than $88 \%$ sorption was obtained even after five sorption/elution cycles. When $0.50 \mathrm{M}$ $\mathrm{HNO}_{3}$ was used for elution, the sorption percentage decreased gradually form 97 to 78 between the first and the fifth cycles. 
Table 5

Spike recovery results obtained using $\left(\mathrm{NH}_{2}+\mathrm{SH}\right)$ silica for a drinking water sample (solution pH 3.0, sorption time: $30 \mathrm{~min}$, sorbent amount: $50.0 \mathrm{mg}$, sample volume: $15.0 \mathrm{~mL}$, sorption temperature: $25^{\circ} \mathrm{C}$, eluent: $0.5 \mathrm{M} \mathrm{NaOH}$, desorption time: $60 \mathrm{~min}$, $n=3)$.

\begin{tabular}{|c|c|c|c|c|}
\hline & \multicolumn{3}{|c|}{ Concentration $\left(\mu \mathrm{g} \mathrm{L}^{-1}\right)$} & \multirow[t]{2}{*}{ Recovery (\%) } \\
\hline & Initial & Spiked & Determined $^{\mathrm{a}}$ & \\
\hline $\begin{array}{c}\text { Ultrapure } \\
\text { water }\end{array}$ & 0.0 & 30.0 & $27.9( \pm 0.7)$ & $93.0( \pm 2.3)$ \\
\hline Drinking water & 2.7 & 30.0 & $28.4( \pm 0.4)$ & $86.9( \pm 1.2)$ \\
\hline $\begin{array}{c}\text { Drinking water } \\
\text { (1/3 diluted })\end{array}$ & 0.9 & 10.0 & $9.0( \pm 0.2)$ & $82.6( \pm 2.1)$ \\
\hline $\mathrm{SRM}^{\mathrm{b}}$ & 26.67 & 0 & $27.53( \pm 0.37)$ & $103.2( \pm 1.4)$ \\
\hline
\end{tabular}

a Concentration determined after sorption/desorption steps.

b SRM solution ( $1 / 3$ diluted).

The highest desorption was obtained using $0.50 \mathrm{M} \mathrm{NaOH}$; however, when this eluent is used the sorbent cannot be used further since the functional groups are deteriorated. In the case of $\mathrm{As}(\mathrm{III})$ sorption, only two sorbents, namely, $\left(\mathrm{NH}_{2}\right)$ silica $+(\mathrm{SH})$ silica and $\left(\mathrm{NH}_{2}+\mathrm{SH}\right)$ silica were investigated for their reusability after elution with $0.50 \mathrm{M} \mathrm{NaOH}, 0.50 \mathrm{M} \mathrm{HNO}_{3}$ and $0.05 \mathrm{M} \mathrm{KIO}_{3}$ in $2.0 \mathrm{M} \mathrm{HCl}$. The results show that only $0.50 \mathrm{M} \mathrm{HNO}_{3}$, with higher than $80 \%$ sorption after the fifth sorption/elution cycle, can be used if the sorbents are to be reused. On the other hand, $0.50 \mathrm{M} \mathrm{NaOH}$ and $0.05 \mathrm{M} \mathrm{KIO}_{3}$ in $2.0 \mathrm{M} \mathrm{HCl}$ can be used only once because of the degradation of the surface functional groups. Nevertheless, these eluents can be used for $\mathrm{As}(\mathrm{III})$ and $\mathrm{As}(\mathrm{V})$ in many applications where the reusability of the sorbent is not of concern.

\subsection{Method validation}

As can be deduced from both the sorption and the desorption results, the bifunctional $\left(\mathrm{NH}_{2}+\mathrm{SH}\right)$ silica is advantageous over the mono-functionalized $\left(\mathrm{NH}_{2}\right)$ silica and $(\mathrm{SH})$ silica, and also the mechanically mixed $\left(\mathrm{NH}_{2}\right)$ silica + $(\mathrm{SH})$ silica. It offers better sorption features for both $\mathrm{As}(\mathrm{III})$ and $\mathrm{As}(\mathrm{V})$ compared to the other sorbents. For this reason, the accuracy of the method was investigated through the analysis of a standard reference material using $\left(\mathrm{NH}_{2}+\mathrm{SH}\right)$ silica as the sorbent. The result obtained with the proposed methodology was $27.53 \pm 0.37 \mu \mathrm{g} \mathrm{L}^{-1}$ which is in good agreement with the certified value of arsenic in the SRM (NIST $1640,26.67 \mu \mathrm{g} \mathrm{L}^{-1}$ ). In addition, a spike recovery test was applied to drinking water to further test the validity of the method. The percent recovery values given in Table 5 indicate that the proposed methodology is practical to use with ultrapure and drinking water as well as SRM with the percentage recovery values of $93.0( \pm 2.3)$, $86.9( \pm 1.2)$ and $103.2( \pm 1.4)$, respectively.

\section{Conclusions}

Modification of silica surface was successively achieved with amine and/or mercapto groups using the functional silanes APTES and/or MPTMS, respectively. The prepared sorbents were used for sorption of $\mathrm{As}(\mathrm{III})$ and $\mathrm{As}(\mathrm{V})$, and the sorption results demonstrated the high specificity of the sorbents. For example, mercaptofunctionalized ( $\mathrm{SH}$ )silica shows selectivity only to $\mathrm{As}(\mathrm{III})$ and retains the species quantitatively at the $\mathrm{pH}$ of 1.0 and 9.0. The mechanism of sorption can be attributed to the chelate formation between the arsenite ions in the solution and the mercapto functional groups on the silica surface. Amine-functionalized $\left(\mathrm{NH}_{2}\right)$ silica, on the other hand, displays sorption towards only As(V) at $\mathrm{pH} 3.0$, due to electrostatic attraction between the protonated amine groups of the sorbent and $\mathrm{H}_{2} \mathrm{AsO}_{4}{ }^{-}$ion which is the predominant species in the solution at this $\mathrm{pH}$. The strong dependence of the sorption of $\left(\mathrm{NH}_{2}\right)$ silica on the solution $\mathrm{pH}$ necessitates the use of a buffer to fix the pH at 3.0 to prevent the possible increase of the $\mathrm{pH}$ to higher values where no sorption of $\mathrm{As}(\mathrm{V})$ occurs. Bifunctional $\left(\mathrm{NH}_{2}+\mathrm{SH}\right)$ silica has shown superior sorption performance compared to the mono-functionalized sorbents in terms of solution $\mathrm{pH}$, sorbent amount, reaction time, reaction temperature, and batch-to-batch reproducibility. Bifunctional $\left(\mathrm{NH}_{2}+\mathrm{SH}\right)$ silica makes the speciation of $\mathrm{As}(\mathrm{III})$ and $\mathrm{As}(\mathrm{V})$ possible by enabling the sorption of both $\mathrm{As}(\mathrm{III})$ and $\mathrm{As}(\mathrm{V})$ species at $\mathrm{pH} 3.0$ and only $\mathrm{As}(\mathrm{III})$ at $\mathrm{pH} 1.0$ or any $\mathrm{pH}$ higher than 4.0. $\mathrm{As}(\mathrm{V})$ can then be determined from the difference. Eluents, such as $0.05 \mathrm{M} \mathrm{KIO}_{3}$ in $2.0 \mathrm{M} \mathrm{HCl}$ and $1.0 \%(\mathrm{w} / \mathrm{w}) \mathrm{L}$-cysteine can be used for the desorption of $\mathrm{As}(\mathrm{III})$ and $\mathrm{As}(\mathrm{V})$, respectively. However, simultaneous quantitative desorption of both $\mathrm{As}(\mathrm{III})$ and $\mathrm{As}(\mathrm{V})$ can only be achieved using $0.5 \mathrm{M}$ $\mathrm{NaOH}$, bearing in mind that this eluent restricts the use of the silica-based sorbents to only once.

The advantageous sorption results obtained for $\mathrm{As}(\mathrm{III}) / \mathrm{As}(\mathrm{V})$ speciation have boosted further research on the application of the bifunctional sorbent to similar species which will be the topic of further studies.

\section{Acknowledgements}

The authors would like to acknowledge The Scientific and Technological Research Council of Turkey for the support of this work through the project $108 \mathrm{~T} 798$ and also the Center of Material Research for the facilities SEM, TGA, XRD, Environmental Research Center for ICP-MS measurements at İzmir Institute of Technology, and Prof. Dr. Klaus Albert (University of Tübingen, Germany) for useful discussions during the XI. National Spectroscopy Congress (June 2009, Ankara, Turkey).

\section{Appendix A. Supplementary data}

Supplementary data associated with this article can be found, in the online version, at doi:10.1016/j.talanta.2011.06.021.

\section{References}

[1] United States Environmental Protection Agency, USEPA, Doc. EPA 815-P-01$001,1999$.

[2] M. Leermakers, W. Baeyens, M. De Gieter, B. Smedts, C. Meert, H.C. De Bisschop, R. Morabito, Ph. Quevauviller, Trends Anal. Chem. 25 (2006) 1-10.

[3] T.S.Y. Choong, T.G. Chuah, Y. Robiah, F.L.G. Koay, I. Azni, Desalination 217 (2007) 139-166.

[4] R. Naidu, E. Smith, G. Owens, P. Bhattacharya, P. Nadebaum, Managing Arsenic in the Environment From Soil to Human Health, CSIRO, 2006.

[5] D. Mohan, C.U. Pittman Jr., J. Hazard. Mater. 142 (2007) 1-53.

[6] P.L. Smedley, D.G. Kinniburgh, Appl. Geochem. 17 (2002) 517-568.

[7] B.K. Mandal, K.T. Suzuki, Talanta 58 (2002) 201-235.

[8] World Health Organization, Guidelines for Drinking-water Quality [Electronic Resource]: Incorporating First Addendum, vol. 1, Recommendations, third ed. 2006.

[9] A.A. Menegario, M.F. Gine, Spectrochim. Acta Part B 55 (2000) 355-362.

[10] J.M. Bundaleska, T. Stafilov, S. Arpadjan, Int. J. Environ. Anal. Chem. 85 (2005) 199-207.

[11] M. Yersel, A. Erdem, A.E. Eroğlu, T. Shahwan, Anal. Chim. Acta 534 (2005) 293.

[12] P. Niedzielski, M. Siepak, J. Siepak, J. Przybylek, Pol. J. Environ. Stud. 11 (2002) 219-224.

[13] J. Dedina, D.L. Tsalev, Hydride Generation Atomic Absorption Spectrometry Wiley, Chichester, 1995

[14] A. Sabarudin, K. Oshita, M. Oshima, S. Motomizu, Anal. Chim. Acta 542 (2005) 207-215.

[15] V. Dufailly, L. Noel, T. Guerin, Anal. Chim. Acta 611 (2008) 134-142.

[16] L. Dambies, T. Vincent, E. Guibal, Water Res. 36 (2002) 36993710.

[17] Y. Xin, L. Zhenhuan, J. Zucheng, C. Jianguo, W. Songqin, Anal. Lett. 32 (1999) 2105-2114

[18] M. Tuzen, D. Çıtak, D. Mendil, M. Soylak, Talanta 78 (2009) 52-56.

[19] C. Huang, B. Hu, Z. Jiang, Spectrochim. Acta Part B 62 (2007) 454-460.

[20] P.K. Jal, S. Patel, B.K. Mishra, Talanta 62 (2004) 1005-1028.

[21] I.M. El-Nahhal, F.R. Zaggout, N.M. El-Ashgar, Anal. Lett. 33 (2000) 2031-2053.

[22] I.M. El-Nahhal, B.A. El-Shetary, K.A.R. Salib, N.M. El-Ashgar, A.M. El-Hashash, Anal. Lett. 34 (2001) 2189-2202.

[23] I.M. El-Nahhal, B.A. El-Shetary, K.A.R. Salib, N.M. El-Ashgar, A.M. El-Hashash, Phosphorus Sulfur 177 (2002) 741-753. 
[24] N.M. El-Ashgar, I.M. El-Nahhal, J. Sol-Gel Sci. Technol. 34 (2005) 165-172.

[25] I.M. El-Nahhal, N.M. El-Ashgar, J. Organomet. Chem. 692 (2007) 2861-2886,

[26] I.P. Blitz, J.P. Blitz, V.M. Gun'ko, D.J. Sheeran, Colloids Surf. A 307 (2007) 83-92.

[27] K.Y. Ho, G. McKay, K.L. Yeung, Langmuir 19 (2003) 3019-3024.

[28] M. Puanngam, F. Unob, J. Hazard. Mater. 154 (2008) 578-587.

[29] A.M. Burke, J.P. Hanrahan, D.A. Healy, J.R. Sodeau, J.D. Holmes, M.A. Morris, J. Hazard. Mater. 164 (2008) 229-234.

[30] J. Hao, M.J. Han, X. Meng, J. Hazard. Mater. 167 (2009) 1215-1221.
[31] L. Dominguez, Z. Yue, J. Economy, C.L. Mangun, React. Funct. Polym. 53 (2002) 205-215.

[32] E. Boyacı, A.E. Eroğlu, T. Shahwan, Talanta 80 (2010) 1452-1460.

[33] X.D. Liu, S. Tokura, M. Haruki, N. Nishi, N. Sakairi, Carbohydr. Polym. 49 (2002) 103-108.

[34] L.N.H. Arakaki, C. Airoldi, Polyhedron 19 (2000) 367-373.

[35] A. Erdem, A.E. Eroğlu, Talanta 68 (2005) 86-92.

[36] F. Zheng, B. Hu, J. Anal. At. Spectrom. 24 (2009) 1051-1061. 